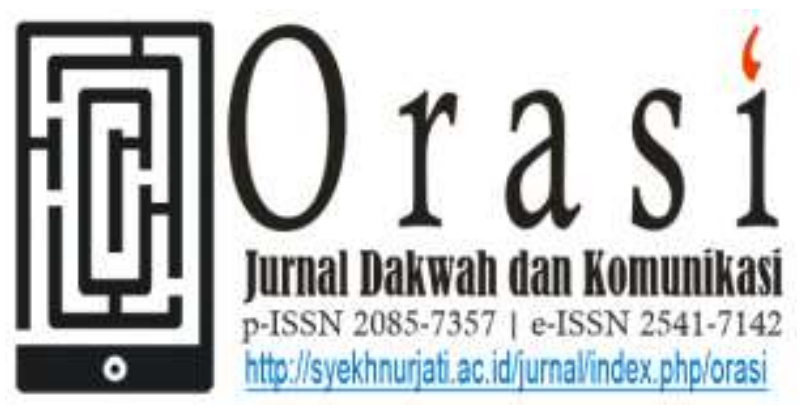

Volume 11 No. 2 Desember 2020

\title{
TEORI SIMULACRA JEAN BAUDRILLARD DALAM DUNIA KOMUNIKASI MEDIA MASSA
}

\section{JEAN BAUDRILLARD'S SIMULACRA THEORY IN THE COMMUNICATION WORLD OF MASS MEDIA}

\author{
Theguh Saumantri ${ }^{1, a)}$, dan Abdu Zikrillah ${ }^{2, b)}$ \\ ${ }^{1}$ Jurusan Sejarah dan Kebudayaan Islam, ${ }^{2}$ Jurusan Komunikasi dan Penyiaran Islam, IAIN Syekh Nurjati \\ Cirebon \\ a) e-mail: saumantri.theguh@gmail.com

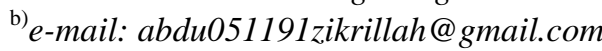

\begin{abstract}
ABSTRAK
Pada era postmodern sekarang ini, masyarakat dikenal sebagai masyarakat yang mengedepankan prestise. Masyarakat kontemporer sudah terikat dan tidak dapat terlepas dari teknologi dan saling menjalin komunikasi dengan cepat, sehingga terbentuk koneksi integral dari pesatnya perkembangan teknologi informasi, kemudian terciptalah sarana transformasi sosial dengan tatanan nilai kemodernan yang serba cepat dan instan. Komunikasi merupakan sebuah dialektika kebutuhan akan menerima informasi. Berkembangnya teknologi komunikasi dan informasi membuat beragam sarana media komunikasi, mulai dari kegunaan dan bentuk alat yang semakin canggih membuat manusia menjadi sangat responsif terhadap informasi yang diterima. Dalam teori simulacra Jean Baudrillrad menjelaskan bahwa realitas dalam media adalah realitas semu dimana sesuatu kebenaran dimipulasi agar masyarakat mengikuti dan mengkonsuminya. Terlebih kita sekarang berada di era post-truth, realitas komunikasi digambarkan sebagai sebuah rentang masa yang cenderung mengabaikan kebenaran dan fakta. Realitas dan kebenaran adalah sebuah persepsi yang terikat pada perspektif dan interpretasi personal. Dalam kajian ini penulis secara deskriprif analitik memberikan penjelasan tentang fenomena yang sering terjadi di dalam realitas masyarakat kontemporer yaitu tentang komunikasi yang ditampilkan dalam media massa. Dari kajian ini dapat diketahui bahwa komunikasi di media massa adalah sebuah potret komunikasi yang sering kali di manipulasi kebenaran dan faktanya.
\end{abstract}

Kata Kunci: Baudrillard, Simulacra, Komunikasi, Media Massa

Orasi: Jurnal Dakwah dan Komunikasi | Volume 11, No. 2, Desember 2020 


\begin{abstract}
In the current postmodern era, society is known as a society that prioritizes prestige. Contemporary society is bound and inseparable from technology and has a high awareness of communication. They tend to be an integral part of the rapid development of information technology. Hence, social transformation media with the value of modernity which is completely fast and instant are brought up to existence. Communication is dialectic of the need to receive information. The development of communication and information technology has created a variety of communication media, ranging from forms to methods, making people highly responsive to any information received. In Simulacra theory, Jean Baudrillrad explains that reality in the media is a false reality in which truth is manipulated so that people will follow and consume it. Moreover, we are now in the post-truth era where the reality of communication is described as a span of time that tends to ignore truth and facts. Reality and truth are perceptions tied to personal perspectives and interpretations. In this study, the writers, in a descriptive analysis, provides an explanation on a phenomenon that often occurs in the reality of contemporary society, namely the communication displayed in the mass media. From this study, it can be concluded that communication in the mass media is a portrait of communication that is often manipulated by truth and facts.
\end{abstract}

Keywords: Baudrillard, Simulacra, Communication, Mass Media

\section{Pendahuluan}

Dalam komunikasi kontemporer sekarang ini, kita bukan kesulitan sumber tetapi terlalu banyak sumber sehingga masyarakat kesulitan dan bingung untuk merepresentasikan sebuah konteks dan kemudian hanya berhenti dan membaca informasi pada sebuah paparan depan atau judul. Dalam kajian kontemporer disebut dengan Divesi ekstase komunikasi yaitu kita kelebihan informasi sehingga tidak dapat mencerna dan memetakan kapan sebuah informasi harus kita yang kita terima adalah sebuah fakta dan kebenaran, yang penting kita pelajari dan diterima begitu saja.

Perkembangan teknologi komunikasi dan informasi berdampak pada beragamnya media komunikasi di kehidupan sehari-hari mulai dengan aktivitas responsif sampai dengan alat komunikasinya. Dunia maya sudah memulai babak baru untuk mengalihkan semua aktivitas manusia (sosial, budaya, agama, politik, ekonomi bahkan seksual) di dunia maya ke dalam bentuk substitusi artifisial manusia. Sehingga yang terjadi adalah masyarakat sedang dalam "perubahan sosial" dan apapun yang dapat dikerjakan di dunia nyata pada saat ini bisa dikerjakan di dalam cyberspace (Piliang 2011). Di era kontemporer yang disandingkan dengan perkembangan teknologi berbagai macam informasi sangat mudah untuk didapatkan, berbagai jenis alat komunikasi diciptakan seperti televisi, radio, internet dan sebagainya yang pada akhirnya memproduksi berbagai macam promosi produk atau yang sering dikenal sekarang dikehidupan masyarakat yaitu dengan istilah iklan. Munculnya iklan di media massa sangat mempengaruhi pola hidup masyarakat dalam berkomunikasi. Perubahan yang di pengaruhi oleh iklan menciptakan lahirnya new life style dikalangan masyarakat 
kontemporer di dasari dengan sifat posmodern. Teknologi informasi kini telah meruntuhkan ruang, tempat, sekat waktu dan jarak pada era digital. Gaya hidup kini bukan lagi bersifat monopoli suatu kasta, tetapi sudah menjadi common. Gaya hidup yang disajikan melalui iklan kini menjadi lebih beraneka ragam dan menyebar bebas sehingga tidak lagi menyimpan nilai yang eksklusif kelas dalam masyarakat. Citra yang ditampilkan iklan bersifat netral yang sangat mudah diikuti, ditiru dan dijiplak kemudian dipakai sesuka hati oleh masyarakat (Chaney 1996).

Konvergensi media teknologi dan sarana informasi yang berkembang masif mulai meluas pesat ke semua aspek, tidak dapat dihandari bisa memiliki berdampak negatif terhadap cara berkomunikasi. Komunikasi di era digital menghadirkan sejumlah perubahan sosial. Perubahan yang terjadi pada kalangan masyarakat kini tidak lagi bagaimana menyerap informasi tentang berita yang tersebar, tetapi disebabkan oleh lemahnya literasi pengetahuan untuk mengolah suatu bentuk informasi valid dan benar. Munculnya media kini menjadi jalan pintas yang dikendalikan oleh sekelompok elit yang memiliki kepentingan untuk memberi masyarakat untuk mendapatkan informasi secara cepat dan menjadikannya alternatif (Syuhada 2018). Minimnya pengetahuan terhadap maraknya media di tengah merebaknya informasi ini ternyata disiasati oleh sebagain kelompok yang memiliki kepentingan agar menghasilkan berita faktual yang mudah diterima oleh masyarakat dan tidak terkonfirmasi kebenarannya atau sering kita disebut dengan hoaks. Media massa dan sosial menjadi alternatif untuk menyebarkan hoaks.

Media massa yang merupakan sarana yang digunakan oleh komunikasi massa untuk menyampaikan suatu informasi, pesan yang bersifat umum kepada masyarakat dengan jumlah yang relatif besar dengan media yang digunakannya adalah jenis perkembangan teknologi seperti televisi, radio dan internet (Wahyudi 2001). Penyebaran hoaks yang masif kini menjadi sebuah fenomena konsumsif netizen setiap hari. Dalam sudut pandang komunikasi, tidak sedikit orang ragu akan kehadiran dan kredibilitas media massa. Tetapi, dari sudut pandang lain, masyarakat juga mudah sekali percaya akan berbagai macam informasi yang di sodori oleh media sosial yang berisi hoaks. Masyarakat dibuat untuk mengbaikan verifikasi kebenaran tentang informasi yang diterima. Kekeliruan informasi pelan-pelan diterima dan menjadi kebingungan bagi masyarakat dalam memcerna suatau berita dan fakta.

Dapat dikatakan hoaks itu bibit di peradaban Post-Truth (Haryatmoko 2017). Era Post-Truth direpresentasikan kecenderungan masyarakat mengonsumsi sebuah informasi faktual dengan tidak melihat suatu kebenaran objektif sehingga untuk memahami sebuah fakta yang ada menjadi berjarak dan bercampur dengan kebenaran palsu. Sementara hoaks dapat dikatakan sebagai kebenaran yang di bungkus oleh kebohongan. Dalam buku yang berjudul 'Trump and The Post-Truth" yang di tulis oleh Ken Willber (Ulya 2018) Istilah Post-truth sendiri selalu 
disandarkan dengan aliaran skeptisisme, nihilisme, narsisme dan post-modernisme, yang mepunyai dasar untuk tidak menerima kebenaran yang bersifat umum atau universal. Kebenaran atau fakta realitas hanyalah interpretasi personal serta tidak memiliki kerangka moral sebagai acuannya. Asumsi filosofis ini menjadi prinsip kerja era posttruth, yang menciptakan wujud fake-news (berita palsu) atau hoaks (kebenaran yang poles dengan kepalsuan). Model komunikasi yang tercipta di masyarakat komtemporer ini dapat kita lihat dari maraknya komunikasi massa yang ditampilkan dalam media. Masyarakat dalam kesehariannya selalu menggunakan media televisi sebagai sarana untuk menerima kumpulan informasi komunikasi kemudian menampilkan suatu produk untuk menjaring masyarakat agar mengikutinya. Selain itu merambahnya internet ke berbagai pelosok dan berbagai macam kalangan menciptakan perubahan sosial dan hal gaya hidup, kebiasaan dan komunikasi.

\section{Metodologi Penelitian}

Penulisan dalam membuat penelitian ini menggunakan penelitian deskriptif kualitatif yang bertujuan untuk mengdeskripsikan sebuah iklan sebagai hyperealitas dalam sebuah komunikasi yang terjadi di masyarakat kontemporer. Metode penelitian kualitatif sendiri adalah sebuah cara yang dapat menjelaskan dan menganalisis sebuah fenomena, aktivitas sosial, sikap, respon, persepsi, serta pemikiran orang secara individu ataupun kelompok masyarakat
(Syaodih 2009). Penelitian ini dibuat agar mampu menganalisis dan mengungkapkan sebuah realitas sosial yang terjadi di masyarakat dalam aktifitas kehidupannya dalam mencerna sebuah komunikasi dalam iklan dari sudut pandang teori simulacra Jean Baudrillard.

Penggunaan metode diskriptif sebagai model yang dapat menjelaskan suatu kondisi objek atau fenomena yang terjadi berdasarkan fakta-fakta dalam rutunitas dikehidupan sehari-hari dan membawa kita untuk memahami objek dan kemudian membuat sebuah kesimpulan umum dari fakta historis (Manawi dan Martini 1994).

\section{Hasil dan Pembahasan}

\subsection{Teori Simulacra Jean Baudrillard}

Jean Baudrillad adalah salah satu filsuf postmodern yang sejajar dengan Derrida, Lacan, Michel Foucault. Riwayat hidupnya Baudrillard dari keluarga petani yang lahir dikota kecil Reims Paris tahun 20 juni 1929 dan meningga 6 maret 2007. Situasi politik yang terjadi di Aljazair pada masa 1950an, membawai pengaruah yang besar terhadap Pendidikannya., sehingga dala keadaan sosiologis yang dialaminya melahirkan pemikiran-pemikiran kritis. Pada tahuan (1958-1966) Baudrillrad menjadi seorang pengajar di Lycee dengan mengampu bahasa jerman yang ia ajarkan pula. Hal ini ia lakukan sebelum selsai kuliah di bawah arahan pembimbing Henri Lefebvre. Baudrillad sangat serius menggulati persoalan filsafat sosial, budaya dan isu kontemporer. Kemudian Dengan kecerdasannya pada semptember 1966 
ia ditunjuk dan mendapat kepercayaan menjadi assisten oleh Lefebvre. Pada masa hidupnya ia bersahabat dengan seorang pemikir semiotik yaitu Roland Barthes, sehingga banyak pemikiran Barthes ini mempengaruhi tulisannya. terlihat dari karyanhya yang berjudul The System of Object (1968) yang banyak di doktrin oleh pemikiran Barthes.

Tokoh yang sangat produktif dan karyanya inspiratif, esay-esay yang di tulis Baudrillard penuh inspirasi membangkitkan inovasi. perhatiannya terhadap hakikat dan pengaruh komunikasi massa masyarakat komtemporer. Selain itu seorang tokoh yang bernama Marshall McLuhan menjadi pemikir yang sangat banyak mempengaruhi Jean Baudrillard tentang pemikiran sosiologinya terutama dalam mengkaji budaya teknologi modern. Pada tahun 1968 di univesitasnya telah terjadi peristiwa demonstrasi yang sangat besar yang dilakukan oleh mahasiswa. Baudrillad pun berpartisipasi dengan membuat sebuah tulisan ilmiah yang berjudul "Utopie" yang menjadikannya alat mediasi agar dapat memberikan gagasan-gagasannya terhadap kritik budaya teknologi yang ia tawarkan dalam kacamata Struktural-Marxis dalam teori-teori tentang media iklan dan pendidikan populer pada masa itu. Analisis Kritis-nya tentang media, teknologi dan pendidikan populer selain dipengaruhi oleh tokoh-tokoh di atas, kemudian dalam mengkaji objektivitas dan analisis sosio-linguistiknya Jean Baaudrillard pun dipengaruhi oleh pemikiran Mercel Mauss, termasuknya strukturasi LeviStaruss dan sosiologi Durkheimian masuk dalam jajaran pengaruh ini. Selain itu ia juga terinspirasi oleh pemikiran Nietzsche, Sartre, Freud, Dostoyevsky, dan Bataille. Meskipun demikian, corak berpikirnya Baudrillard sangatlah besar dipengaruhi oleh Marxisme.

Dalam karya yang berjudul Simulacra and Simulations (1985), Jean Baudrillard menyebutkan bahwa masyarakat simulasi adalah bentuk karakter identitas masyarakat kontemporer dalam kehidupannya selalu dibuat repot dengan sebuah absurditas kode, tanda dan simbol, dan bentuk model sebagai memproduksi dan reproduksi dalam sebuah teori yang ia sebut simulacra. Dalam simulacra Secara esensial manusia itu tidak ada dalam kehadiran realitas sesungguhnya tetapi selalu berpikir imajiner dan ada pada delusi dalam melihat realitas di ruang tempat mekanisme simulasi berlangsung. keadaan ini membuat jarak-jarak antara kebenaran dan kepalsuan, realitas dan rekaan terasa jauh dan memiliki kesamaan. Oleh karena itu yang dihasilkan dalam realitas ini adalah keadaan semu dan kepalsuan hasil simulasi (hyper-reality). Dalam analisis kemajuan teknologi virtual, Baudrillard menjelaskan bahwa realitas semu dan rekayasa atau manipulasi adalah keadaan di mana manusia terjebak dalam realitas yang dianggap asli dan nyata. Dalam dunia simulasi, yang menjadi gambaran suatu realitas adalah model-model manipulasi bukan kenyataan yang sesungguhnya (Baudrillard 1985). Simulacra dimaksudkan untuk mengkontrol masyarakat dengan cara yang halus yaitu menipu dan mempercayai bahwa simulasi itu adalah kenyataan yang sesungguhnya sehingga masyarakat menjadi tergantung terhadap simulasi dan posesif 
terhadapnya. Dan pada akhirnyamanusia menjadi tidak sadar akan hadirnya simulasi ini.

Perkembangan teknologi dan dunia virtual menurut Baudrillard sudah menjadi bagian dari sistem kehidupan manusia. Seperti halnya peralatan canggih komputer, internet, atau iklan yang telah mampu membuat sebuah realitas dan bernostalgia dengan masa lalu. Terlebih, semua yang diciptakan itu mampu memproduksi kenyataan dunia baru yang sesungguh itu adalah sekedar fantasi, ilusi dan halusinansi sehingga terlihat seperti sebuah realitas sungguhan. Lebih jauh, dengan teknologi realitas yang yang diciptakan melampui yang sesungguhnya dan menjadi mode acuan bagi masyarakat dewasa ini.

Istilah simulacra merupakan sebuah sebuatan teori untuk menjelaskan sebuah simbol atau tanda dan citra yang tampak dalam realitas yang tidak ada rujukan dalam kebenaran keberadaannya. Akan tetapi simulasi ini menciptakan sebuah citra, tanda, dan simbol yang kemudian menjadi bagian dari sebuah realitas. Menurut Baudrillard pada saat ini komunikasi interaksi yang ditampilkan oleh media massa cenderung mengabaikan realitas yang susungguhnya. Setiap orang dapat dengan mudah menerima informasi yang dihasilkan dalam dunia virtual yang berbentuk iklan dengan menampilkan hasil yang sempurna sehingga orang tergiur untuk dapat meniru apa yang disampaikan dalam iklan. Iklan menjadi model dari simulcra karena komunikasi yang ditampilkan seolah-olah adalah sebuah realitas sebenarnya sehinggga masyarakat yang melihatnya mengikuti gaya komunikasi yang diserap dalam iklan media massa yang sesungguhnya itu adalah manipulasi. Tidak ada kebenaran yang absolut yang ditampilkan dalam iklan, semua itu adalah simulasi.

Simulacra membentuk sebuah citra yang tidak memiliki proses referensi oleh Baudrillrad disebut dengan simulacrum. Simulacrum adalah tahapan pembentukan citra yang sama sekali tidak memiliki hubungannya terhadap kenyataan realitas. Baudrillard memberikan contoh citra simulacra yang hadir di dunia adalah kehadiran Disneyland,

Baudrillad menulis dalam bukunya "Disneyland adalah model sempurna semua gambaran dari simulacra. Di dalamnya terdapat sebuah permainan ilusi dan permaianan bayangan impian seperti banyak laut dan gambaran masa depan. Dunia khayalan mampu dan sukses mengoperasikan dunia" (Baudrillard 1985).

Sangat jelas sekali pendapat Baudrillrad tentang Disneyland adalah refresentasi dari dunia ilusi dan fantasi yang tidak pernah ada sebelumnya. Kehadairannya dalam realitas dalam sebuah bentuk pikiran imajiner yang tercipta sebagai simulacrum, sebagai simulacra disneylad memperlihatkan kenyataannya bahwa ia mampu menapilkan dunia yang terlihat nyata bahkan kenyataannya melibihi realitas sesungguhnya. Dan Perkembangan teknologi yang sangat canggih dan luar biasa kini mampu memudahkan setiap individu yang terpisah oleh ruang dan jarak bahkan waktu untuk berkomunikasi langsung, hal ini juga menjadi bentuk dari simulasi dan simulacra. Maraknya pengguna media sosial seperti WhatsApp, Facebook, Twitter dan 
Instagram, dan yang lainnya adalah media masa yang menjadi sarana yang digunakan oleh masyarakat saat ini untuk nelakukan berkomunikasi dan berinteraksi berbagi informasi antara individu dengan individu yang lain, yang berkomunikasi di dunia maya secara langsung, pada waktu yang sama tetapi mereka bisa berada di tempat yang berbeda. Dengan ini masyarakat mampu secara instan dimanapun dan kapanpun untuk melakukan komunikasi memalui jejaring sosial yang sering digunakan tersebut. Tetapi komunikasi yang terjadi di media massa ini membuat orang menjadi bebas, artinya dengan akun yang di miliki di akun media sosial, mereka dapat membuat identitas semaunya, status, bahkan pengunaan foto, menyebarkan berita dan yang lainnya, informasi yang tampilkan oleh mengguna media sosial semuanya yang dicantumkan bukanlah identitas yang sebenarnya, mereka dapat memanipulasi semua bentuk kebenaran dalam dirinya yang sesungguhnya dibuat dan diarahkan untuk menbuat komunikasi dan menjalin pertemanan baru di dunia maya. Komunikasi dan interaksi yang diciptakan bisa membuat sebuah dialektik aktif di mana orang-orang saling mengomentari tulisan yang dibuatnya, dan foto yang di upload bahkan informasi yang disajikan di dunia maya, sehingga situasi inilah yang disebut oleh Jean Baudrillard menjadi model dari simulacra karena terjadinya komunikasi dan interaksi dalam masyarakat pada masa ini terjadi bukan pada kenyataan yang sesungguhnya, namun berlangsung di dunia maya yang tak terbatas, dan mereka anggap lebih nyata dan dekat dari realitas yang sebenarnya.

Dalam teori simulacra Jean Baudrillard masyarakat kontemporer di bawa kepada realitas virtual, fenomena seperti ini menjadi budaya konsumsi citra yang di tawarkan oleh media massa. Simulasi yang ditampilkan membuat masyarakat menjadi terpurung. Masyarakat di giring pada kenyataan realitas yang palsu yang diciptakan oleh simulasi. Realitas yang bukan keadaan sebenarnya yang kemudian dicitrakan dalam bentuk realitas yang mendeterminasikan kesadaran masyarakat, inilah yang disebut dengan realitas semu (hyper-reality). Realitas seperti ini tercipta oleh jennis-jenis media yang dijadikan acuan referensi untuk masyarakat pada umumnya. Dengan media, dunia imajinasi terbentuk dan disusughkan oleh simulator dan pak akhirnya menggiring masyarakat pada suatu kesadaran palsu di ciptakan oleh simulator tersebut. Keadaan seperti inilah yang dikatakan oleh Baudrilard ruang simulacra. Dalam mengonsepkan era kontemporer Baudrillrad menyebutkan dengan sebutan mass (massa) yang menjadi konspetualisasi keadaan masyarakat yang sudah tercampuri oleh faktor budaya simulacra. Disiilah perkembangan teknologi dan informasi dapat terlihat menjadi realitas yang mampu di klaim sebagai bentuk produk dari modernitas yang menciptakan batasanbatasan imajiner dalam realitas dan diciptkan oleh sebuah proses simulasi. Citra simulasi mengantar realitas kepda heperrealitasyang digambarkan sebagai ruang kosong yang didalamnya antara yang real dan yang imajiner 
tidak ada lagi batasan. Sehingga simulasi ini tidaknya hanya berbicara tentang tanda dan simbol tetapi berbicara soal kekuasaan dan hubungan sosial dalam masyarakat, di mana keadaan masyarakat ini yang berlaku adalah tanda yang asli yang tidak memiliki rujukan.

Makna pesan yang ditampilkan oleh media massa kini bagaikan komunikasi yang terputus dari tempat asalnya, sehingga tepat sekali Baudrillard membuat sebuah kesimpulan bahwa kontruksi budaya sekarang selalu ada dalam citra-citra semulasi, yakni menciptakan suatu realitas nyata tanpa historisitas kebenaran yang disebut dengan hoperrealitas (Baudrillard dalam Fitria 2015).

\subsection{Hiperrealitas}

Media komunikasi kontemporer adalah media yang memproduksi rangkaian simulacrum, yang menerjemahkan dan mengarahkan apa yang disebut dengan realitas dan merumuskan apa yang sering dikenal dengan kebenaran kenyataan di tengah masyarakat dewasa ini. Citra yang ditampilkan dalam media massa tidak semerta-merta menjadi alat komunikasi yang merepresentasikan suatu realitas yang sesungguhnya, melainkan manipulasi realitas atau realitas buatan, akan tetapi masyarakat dapat diarahkan untuk mengikuti dan mempercayainya sebagai bentuk kebenaran (Piliang 2001). Komunikasi yang ditayangkan dalam media massa maupun di mesia sosial menciptakan realitas semu. Menurut Baudrillard, munculnya hiperrealitas menghapus defferensiasi dua dunia yaitu antara dunia nyata dengan hiruk pikuk realitasnya dengan dunia imajiner dengan segenap fantasi yang dibawanya (Lechte 2001). Dunia dalam hiperrealitas menyuguhkan sebuah keadaan yang terciptadari citra yang menyerupai orosinalitas, masa lalu yang menjadi satu dengan masa kini, simbol bercampur dengan realitas, fakta yang di pernak menjadi rekayasa, dan kepalsuan yang giring menjadi sebuah keaslian. Framingframing kenyataan fakta, manipulasi, berita, hoax dan kebenaran realitas sudah bercampur aduk dalam ruang ini, situasi ini kemudian menciptakan sebuah kesadaran dalam diri (self consciousness) yang memiliki dasar bawaan bahwa semua yang ditampilkan adalah palsu (Utoyo 2001). Iklan yang ditayangkan dalam layar media massa untuk dikonsumsi oleh masyarakat menampilkan sebuah tayangan realitas baru yang pada kenyataannya itu jauh dari realitas sesungguhnya, tetapi penayanganpenayangan itu selalu diputar berulang dalam sebuah media yang akhirnya membentuk komunikasi massa seakan-akan menjadi kenyataan yang asli dan mereka menerimanya sebagai realitas yang sebenarnya.

Seperti halnya sebuah produk dengan iming-iming yang menggoda ditawarkan dalam sebuah iklan media massa, contoh dalam iklan rokok yang memberikan kepuasan terhadap orang yang mengkonsumsinya dikelilingi para wanita cantik, kemudia iklan yang newamarkan produk perawatan tubuh wanita seperti shampo, parfum, body lotion, komsetik dan sebagainya, dalam iklah tersebut ditampilkan para model wanita yang tercantik dan anggun untuk menarik perhatian. Bentuk yang ditampilakan oleh para artis iklan adalah wanita yang berparas cantik, berkulit putih, 
tubuh langsing dan berambut panjang halus, sehingga yang dicitrakan oleh para model dalam iklan tadi menjadi sebuah referensi realitas bahwa tampilan seorang wanitaitu seakan sempurna dan didamba-dambakan jika memiliki bentuk yang sama yang dicirikan dalam iklan.

Melalui kondisi ini, bahasa dan tanda dalam komunikasi yang ditampilkan merepresentasikan kenyataan yang sebenarnya, nyatanya adalah itu sebuah realitas buatan atau bisa disebut "realitas artifisial" yang dibuat oleh teknologi simulasi sedemikian rupa, sehingga pada tahap tertentu realitas media ini memiliki dampak dipercaya sebagai sebuah realitas yang nyata atau bahkan lebih nyata dari realitas sesungguhnya.

Ketika tidak ada lagi kebenaran dalam realitas dan masyarakat masuk dalam alam heperrealitas, meraka kehilangan kesadaran bahwa apa yang dilihat sebagai suatu kebanaran sesungguhnya adalah kontruksi atau rekayasa realitas diteampakan lewat teknologi informasi. Oleh karena itu terjadilah peralihan dunia realitas dan tatanan sosial budaya komunikasi yang bersifat alamiah oleh simulasi dan dalam model artifisial teknologi. Berdasarkan data yang diliris oleh Kementerian Komunikasi dan Informatika (Kominfo) menyebutkan masyarakat pengguna internet di seluruh Indonesia tercatat mencapai 171 juta pada tahun 2019. Di setiap tahun pengguna internet bertambah 10,2 persen atau 27 juta jiwa. Platfcorm media sosial yang paling banyak diaskses adalah Facebook dengan persentase 50,7 persen, diikuti Instagram 17,8 persen dan Youtube 15, 15 persen (Gatra.com 2019). Artinya masyarakat Indonesia kini sudah menjadi pemikmat paling banyak dan aktif menjadi konsumen tanda dalam menggunakan layanan virtual. Ketidaksadaran masyarakat dalam bermedia sosial yang disetir oleh tanda/simbol dan kode, menghantarkan pada karancuan mengidentifikasi identitas yang asli dan semu. Masyarakat kontemporer pada akhirnya memiliki dua identitas; identitas real dan identitas virtual.

Dalam dunia nyata, identitas adalah ciri "satu tubuh, satu identitas". Tapi dalam dunia virtual, seseorang dalam dunia nyata mampu membuat beberapa identitas virtual sesuai kemauan dan konsepsinya, ia dapat menjadikan dirinya menjadi seseorang yang didesain bijak, cerdas, tampan dan anggun bahkan terlihat richman. Hal ini dipengaruhi dari perputaran citra, kodem informasi, gaya dan fashion yang tanpa henti, yang telah mendokrin perhatian (perception) dan kesadaran (consciousness) masyarakat di dalam mekanisme kecepatan. Inilah yang disebut oleh Baudrillard sebagai Ecstasy of Communication. "hilangnya transdensi atau kedalaman, yang ada hanya permukaan operasional yang bersifat imanen, permukaan komunikasi yang halus dan fungsional". Fenomena hipperrealitas membentuk hubungan manusia kedalam kondisi realitas yang dimainkan oleh citra tertentu. Masyarakat terpenjara di suatu dunia yang di manipulasi, dunia yang tidak pernah berhenti berlari dan berinovasi, serta tidak tidak pernah mengurangi tempo konsumsinya. 
3.3 Terciptanya Ekstasi Komunikasi dalam Media Massa

Baudrillard berpandangan bahwa
dunia kontemporer sesuatu yang ekstasi
(escatic). Ekstasi memiliki makna yang metamorfosis yang tidak kondisional, eskalasi untuk kepentingan eskalasi, proses perjalanan di luar kontrol yang terus menerus sampai semua esesnsi hilang. Pada akhirnya, sestem yang di luar kontrol ini menciptakan ruang kehampaan dan ketidakbermaknaan. Baudrillard berkata "ekstasi seterusnya bercahaya dalam bentuk asli dan hampa (Ritze 2003).

Refleksi atas media massa berdasarkan pemikiran Jean Baudrillard memiliki nilai atas pembentukan sosiol culture dalam masyarakat kontemporer dan memberikan partisipasi kritik bagi cara komunikasi masyarakat dewasa ini. Bagimanapun juga, Cara komunikasi dalam media massa dilihat dari perspektif filsafat sosial dapat dinilai sebagai proses pembentukan persoalan sosial dimana terdapat struktur yang paling dasar dalam realitas yang menjadi habit masyarakat dan persoalan bagaimana cara mereka menciptakan dunia komunikasi di dunia simulasi yang kontrol oleh media massa.

Dalam dunia ekstasi, Massa bisa dipahami sebagai bentuk asli dan juga hampa yang berjalan di luar kontrol dan dalam proses pencapaian batas sosial. Berbeda dengan model komunikasi secara langsung yang menggunakan komunikasi naratif dalam realitas secara real. Komunikasi media massa bertumpu pada bangunan dunia realitas dan memiliki sifat eksistensi subjek begitu berperan melampaui batasan "ruang konseptual" dengan gerak jelajah aktivitas logika menjadi separuh nyata dan tidak terbatas (Barker 2011).

Pergeseran perpektif komunikasi yang mengedepankan hedonisme dan kebebasan menjadi persoalan masyarakat modern dewasa ini. Masyarakat modern saat ini pun menjadi sudah terbiasa untuk melanggar atau terlibat dalam persoalan-persoalan wilayah komunikasi. Fenomena yang mencolok dari dunia digital ini adalah pesatnya perkembangan teknologi komunikasi yang menciptakan realitas baru dalam dunia maya (virtual worlds) bagi masyarakat diseluruh dunia dewasa ini.

Baudrillard mengatakan bahwa komunikasi ini dapat diibarakatkan sebagai lingkaran magis, yang merubah segala aktivitas dalam dunia yang nyata menuju ke ruang imajiner dalam dunia konseptual. Media massa sudah menciptakan lingkaran magis dengan cara konstruksi terhadap realitas yang memiliki jangkauan tak terbatas dan tak lagi memiliki kesamaan. Teknologi hadir dengan segala kecanggihan yang diciptakan dari perangkat lunak dan keras yang dimilikinya menciptakan citra digital yang kini menjadi bagian yang tak bisa dipisahkan dari manusia. Sehingga terciptalah dunia baru yang disebut augmented reality di mana sistem perangkat lunak mampu membuat suatu kenyataan virtual. Dalam augmented reality ini, teknologi virtual menjadikan dunia menjadi tek berjarak antara kebenaran yang sesungguhnya dengan dunia yang unreal. 
Namun dalam kacamata filsafat kant, kajian tentang fenomena komunikasi teknologi modern digambarkan sebagai fenomenologi realitas, yang membentuk realitas menjadi das ding ansich. Dalam rutinitasnya menampakkan diri dan memiliki tujuan yakni keadaan sebagai noumenon dan kenyataan menjadi fenomenon (dua distingsi realitas). Maka, pengetahuan disekitar kita adalah buah dari konsepsi pikiran dan pengalaman inderawi adalah sebagai fenomena. Fenomena yang dihasilkan dari noemena (dasar kenyataan dari sebuah objek dalam dirinya yang tidak mungkin untuk diketahui). Hanya pengalaman yang bersumber dari inderawilah yang bisa di jadikan pengetahuan dalam fenomena. Oleh karna itu logika pikiran kita memiliki daya untuk menciptakan pengalaman dan mengalaman pengorganisasikan pengetahuan itu. Sesungguh dalam pengetahuan idea objek dan kategori logika mampu menyesuikan satu sama lain tepai dalam pandangan realismenya aristotelian objek tidak mampu untuk menyesuaikan dengan kategori-kategori logika. Pandangan Kant terhadap konsep tanda persepsi tidak memiliki arti apapun, sebagaimana halnya persepsi tanpa konspe adalah buta (Murtiningsih, Siswanto, dan Syamsudin 2013).

Keberadaan masyarakat yang dikelilingi oleh tanda kini menikmati sebuah media yang berbicara akan dirinya sendiri. Hal ini dipaparkan oleh Baudrillard mengenai media yang sudah kehilangan meaning tidak lagi memiliki sebuah pesan yang bermakna. Dulu media sebagai sarana dan medium untuk menyampaikan pesan, namun kini media telah menjadi pesan itu sendiri (Kushendrawati 2001). Namun masyarakat selalu berada dalam realitas sosial yang berbaur dengan tanda dan tak mungkin tidak mempengaruhi kehidupannya. Masyarakat tidak mungkin bisa menghindari tanda-tanda tersebut. Kondisi seperti ini dinamakan dengan ekstasi komunikasi. Tanda-tanda dikemas oleh media untuk direproduksi dalam berbagai bentuk untuk dikonsumsi oleh masyarakat sebagai dosis tinggi harian. Hal tersebut bukanlah konsumsi yang menyehatkan untuk masyarakat melainkan ekstasi yang diberikan ke dalam pemikiran masyarakat yang memasuki dunia ilusi, fantasi, dan kenikmatan tak terbatas. Media memainkan peran kunci pada bentuk situasi ini. Kita dibombardir oleh informasi media yang berperan dalam menciptakan kedangakan dan kesederhanaan dunia. Segala sesuatu besar dan kecil merupakan sekrup kecil darinya dan sangat sulit untuk membedakannya. Akibatnya, kesadaran masyarakat bukan lagi kesadaran yang alamiah, melainkan kesadaran yang tertutupi oleh ekstasi informasi (Kushendrawati 2001).

Simulasi dalam media memiliki kemampuan yang menciptakan segala bentuk kemungkinan hingga kemungkinan yang tak pernah terbayangkan yang terus mereproduksi tanda ke dalam masyarakat. Kemampuan menanipulasi dan menyebarkan tanda tidak mempunyai batasan sehingga setiap media yang menampilkan simulasi mampu melampaui segala bentuk batasan-batasan yang ada, bukan dari batasan di mana masyarakat modern pun tidak pernah 
menyangkal hal tersebut bisa dilakukan. Menurut Baudrillard, media yang menciptakan simulasi dapat mengukir suatu tanda yang mampu membuat masyarakat tidak dapat lagi mengetahui mana yang otentik dengan yang tiruan, semua membaur menjadi satu dan sulit untuk dipisahkan dan dibedakan (Baudrillard 1985).

\section{Simpulan dan Saran}

Perubahan pola dan perilaku masyarakat dalam berkomunikasi dan menerima informasi tidak terlepas dengan hadirnya media alternatif. Masyarakat dewasa ini sudah terbiasa menggunakan mendia massa berkomunikasi dalam kehidupan sehari-hari komunikasi yang diciptakan oleh kemajuan teknologi kini menjadi model komunikasi postmodern yang memiliki peran operasional dalam paradigma kecepatan dan simulasi yang di dalamya tanda dan bahasa yang membawa masyarakat ke dalam simulacra. Dalam dunia sumulasi, manusia telah menempati ruang imajiner yang menyatu dengan realitas, yaitu di mana diferensiasi dunia real dan fantasi begitu sangat sulit dibedakan, masyarakat hidup di dalam satu ruang yang dipenuhi dengan dunia imajinasi yang menampilkan se akan-akan itu adalah sebuah kenyataan yang sesungguhnya. Menurut Jean Baudrillrad masyarakat kontemporer sekarang ini menikmati kondisi hidup dengan zaman simulacra, kenyataan yang dilihat dan media iklan disekitar kita adalah reproduksi realitas yang dihasilkan dari konsepsi simulasi.

Kemajuan zaman diiringi dengan kemajuan teknologi serta kecanggihannya telah merubah gaya komunikasi masyarakat kontemporer dalam media massa dan dunia virtual pun kini telah menuai dampak kultur sosial dari satu komuitas ke komunitas lain. Oleh karena itu, dibutuhkan sebuah pendekatan metodologi akademik yang kritis untuk dapat menjelaskan fenomena munculnya dunia simulacra pada komunikasi media massa. Karena tidak ada lagi kebenaran realitas dalam dunia simulacra ini. Hanyalah sebuah dunia imajiner dan manipulasi citra yang menggambarkan realitas dalam media massa. Dengan pendekatan kajian simulacranya Jean Baudrillad sebuah fenomena komunikasi yang terjadi di media massa memberikan kesadaran kepada kita bahwa simulasi telah mampu menciptakan sebuah relasi komunikasi di tengah masyarakat saat ini. Maka jika menelaah teori simulcara dan dunia hiperrealitas dengan baik masyarakat akan diarahkan dengan baik agar dapat terjaga dari segala bentuk yang di tampilkan oleh media sehingga alur pergeseran intelektual dan gaya komunikasi bisa semakin berkualitas bagi masyarakat di masa depan. Dengan teori simulacra Baudrillard mengingatkan kita semua bahwa hakikat kenyataan manusia di tengah kemajuan dan kecanggihan teknologi sebuah realitas yang real dapat berubah menjadi suatu kenyataan yang bukan keadaan sebenarnya yang di provokasi oleh teknologi.

\section{Daftar Pustaka}

Barker, Chris. 2011. Cultural Studies : Teori Dan Praktik. Penerjemah. Yogyakarta: PT Bentang Pustaka.

Baudrillard, Jean. 1985. Simulacra and 
Simulations. London: Sage Publications Ltd., Galilee \& University of Michigan.

Chaney. 1996. Lifestyle: Sebuah Pengantar Komprehensif. Edited by Nuraeni. Yogyakarta: Jalasutra.

Fitria, Herlinda. 2015. "Hiperrealitas Dalam Social Media (Studi Kasus: Makan Cantik Di Senopati Pada Masyarakat Perkotaan)." Informasi 45 (2). https://doi.org/https://doi.org/10.21831/in formasi.v45i2.7985.

Gatra.com. 2019. "Hingga Juni 2019, Pengguna Internet Indonesia 171 Juta." GATRAcom, July 3, 2019. https://www.gatra.com/detail/news/4260 59/teknologi/hingga-juni-2019pengguna-internet-indonesia-171-juta.

Haryatmoko. 2017. "Ketika Emosi Dominasi Politik." Kompas.Id. 2017. https://kompas.id/baca/opini/2017/11/15/ ketika-emosi-dominasi-politik/.

Kushendrawati, Selu Margaretha. 2001. Hiperrealitas Dan Ruang Publik: Sebuah Analisis Cultural Studies. Jakarta: Penaku.

Lechte, John. 2001. 50 Filsuf Kontemporer: Dari Strukturalisme Sampai Postmodernitas. Terjemahan. Yogyakarta: Kanisius.

Manawi, Hadari, and Mimi Martini. 1994. Penelitian Terapan. Yogyakarta: Gadjah Mada University Press.

Murtiningsih, Siti, Joko Siswanto, and M. Mukhtasar Syamsudin. 2013. "Problem Pendidikan Video Games Dalam Perspektif Teori Simulacra Jean Baudrillard.” Jurnal Ilmu Pendidikan 19 (1). https://doi.org/http://dx.doi.org/10.17977 /jip.v19i1.3758.

Piliang, Yasraf Amir. 2001. "Postmoderinsme Dan Ekstasi Komunikasi." Mediator: Jurnal Komunikasi 2 (2): 166-68. https://doi.org/https://doi.org/10.29313/m ediator.v2i2.716.

2011. Dunia Yang Dilipat; Tamasya
Melampaui Batas-Batas Kebudayaan. Bandung: Matahari.

Ritze, George. 2003. Teori Sosial Postmodern. Terj. Muha. Yogyakarta: Kreasi Waca.

Syaodih, Nana. 2009. Metode Penelitian Pendidikan. Bandung: Remaja Rosdakarya.

Syuhada, Kharisma Dhimas. 2018. "Etika Media Di Era 'Post-Truth."' Jurnal Komunikasi Indonesia 6 (1): 75-79. https://doi.org/https://doi/org/10.7454/jki .v6i1.8789.

Ulya. 2018. "Post-Truth, Hoaks, Dan Religiusitas Di Media Sosial." Fikrah: Jurnal Ilmu Aqidah Dan Studi Keagamaan $6 \quad$ (2): 283. https://doi.org/http://dx.doi.org/10.21043 /fikrah.v6i2.4070.

Utoyo, Bambang. 2001. "Perkembangan Pemikiran Jean Baudrillard: Dari Realitas Ke Simulakrum." Universitas Indonesia.

Wahyudi, J. B. 2001. Dasar-Dasar Jurnalistik, Radio Dan Televisi. Jakarta: Grafiti. 
260 Theguh Saumantri dan Abdu Zikrillah

(Halaman ini sengaja dikosongkan untuk kebutuhan tata letak)

Orasi: Jurnal Dakwah dan Komunikasi | Volume 11, No. 2, Desember 2020 